\title{
INFLUENCE OF GENETIC FACTORS ON THE PRODUCTIVITY OF COWS
}

\author{
Yu. P. POLUPAN, Yu. F. MELNIK, O. D. BIRIUKOVA \\ Institute of animal breeding and genetics nd. a. M.V.Zubets of National Academy of Agrarian Science \\ (Chubynske, Ukraine) \\ yupolupan@ukr.net
}

The research was carried out in the herd of the State enterprise experimental farm "Khristinivske" on cows of Ukrainian Red-and-White dairy and Holstein breeds, taking into account the conditional blood rate for improving Holstein. Breeding work ensured a gradual increase in the dairy production of the herd. The biological regularity of cows to increase dairy productivity with age has been implemented. According to the first-calf cows, a trend of curvilinear increase in productivity with an increase in the conditional share of heredity for the Holstein breed was noted. In cross-breed comparisons, a statistically significant excess of Holstein heifers milkyield over such cows of Ukrainian Red-and-White dairy breed $(404 \pm 158.0 \mathrm{~kg}, \mathrm{td}=2.57, P<0.02)$, which is leveled before the third lactation, was found. A statistically significant effect of linear affiliation (on average $8.3 \%$ ) and paternal origin (13.1\%) on the variability of individual traits of live weight, dairy production and reproductive ability of cows was established. The influence of the father in the studied herd is 1.58 times more significant than that of linear affiliation. A significant level of differentiation of the groups of cows of different lines, sibling groups and half sisters by father by milk for the first lactation was revealed. Based on the totality of assessments of the improving effect and phenotypic consolidation, the most desirable for further use in the herd are the prepotent improvers Tumpi ET Red Tl 112367468 and Mitchell Red 402213, and the most undesirable are the prepotent detergents Inhibitor ET Red 402151 and Jopi Red Tv Tl 114386090.

Keywords: genetic factors, Ukrainian Red-and-White dairy breed, Holstein breed, dairy productivity, live weight, reproductive ability

\section{ВПЛИВ ГЕНЕТИЧНИХ ЧИННИКІВ НА ПРОДУКТИВНІСТЬ КОРІВ} Ю. П. Полупан, Ю. Ф. Мельник, О. Д. Бірюкова

Інститут розведення і генетики тварин імені М.В.Зубия НААН (Чубинське, Украӥна)

Дослідження проведено в стаді ДП ДГ “Христинівське” на коровах української червоно-рябої молочної та голштинської порід з урахуванням умовної кровності за поліпшувальною голштинською. Селекиійна робота забезпечила поступове зростання молочної продуктивності стада. Реалізовано біологічну закономірність корів до збільшення молочної продуктивності з віком. За надоєм первісток відмічено тенденцію до криволінійного підвищення продуктивності зі зростанням умовної частки спадковості за голитинською породою. За міжпорідного порівняння встановлено статистично значуще перевищення надою голштинських

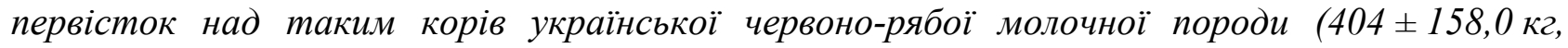
$\left.t_{d}=2,57, P<0,02\right)$, яке до третьої лактачії нівелюється. Встановлено статистично значущий вплив лінійної належності (у середньому 8,3\%) і походження за батьком (13,1\%) на мінливість окремих ознак живої маси, молочної продуктивності та відтворювальної здатності корів. Вплив батька у досліджуваному стаді в 1,58 рази істотніший за такий лінійної належності. Виявлено істотний рівень диференціації груп корів різних ліній, споріднених груп $i$ напівсестер за батьком за надоєм за першу лактащію. За поєднанням оиінок поліпшувального 
ефекту і фенотипової консолідованості найбільш бажаним для подальшого використання у стаді є препотентні поліпшувачі Тумпі Ет Ред Тл 112367468 і Мішель Ред 402213, а найбільш небажаними - препотентні погірмувачі Інгібітор Еm Ред 402151 i Джупі Ред Тв Тл 114386090.

Ключові слова: генетичні чинники, українська червоно-ряба молочна порода, голштинська порода, молочна продуктивність, жива маса, відтворювальна здатність

\section{ВЛИЯНИЕ ГЕНЕТИЧЕСКИХ ФАКТОРОВ НА ПРОДУКТИВНОСТЬ КОРОВ}

\section{Ю. П. Полупан, Ю. Ф. Мельник, О. Д. Бирюкова}

Институт разведения и генетики животных имени М.В.Зубияа НААН (Чубинское, Украина)

Исследования проведены в стаде ГП ОХ “Христиновское” на коровах украинской красно-пёстрой молочной и голштинской пород с учётом условной кровности по улучшающей голштинской. Селекционная работа обеспечила постепенный рост молочной продуктивности стада. Реализована биологическая закономерность увеличения молочной продуктивности коров с возрастом. По надою первотёлок отмечена тенденции криволинейного повышения продуктивности с возрастанием условной доли наследственности голштинской породы. При межпородном сравнении установлено статистически значимое превышение надоя голштинских первотёлок над таким коров украинской красно-пёстрой молочной породы $\left(404 \pm 158,0 \kappa 2, t_{d}=2,57, P<0,02\right)$, которое до третьей лактации нивелируется. Установлено статистически значимое влияние линейной принадлежности (в среднем 8,3\%) и происхождения по отиу $(13,1 \%)$ на изменчивость отдельных признаков живой массы, молочной продуктивности и воспроизводительной способности коров. Влияние отца в исследуемом стаде в 1,58 раза более существенное, чем линейной принадлежности животных. Определили существенный уровень дифференциации групп коров разных линий, родственных групп и полусестёр по отиу по надою за первую лактацию. По совокупности оценок улучшающего эффекта и фенотипической консолидированности наиболее желательныли для дальнейшего использования в стаде являются препотентные улучшатели Тумпи Ет Ред Тл 112367468 и Мишель Ред 402213, а наиболее нежелательными - препотентные ухудшатели Ингибитор Ет Ред 402151 и Джупи Ред Тв Тл 114386090.

Ключевые слова: генетические факторы, украинская красно-пёстрая молочная порода, голштинская порода, молочная продуктивность, живая масса, воспроизводительная способность

Introduction. The Ukrainian Red-and-White dairy breed of cattle remains one of the main (second by livestock and third by dairy productivity) in the controlled part of the dairy cattle population in Ukraine [2, 5-7, 17]. The prospective breeding program for 2020 [14, 17] provides for genetic improvement of herds for the use of boogers of enhancers of both domestic and foreign breeding. Considering the desire of livestock owners to fix the stock of Holstein breed bulls with higher breeding index by breeding stock, the contingent share of hereditary breeding succession increased from $75-82.5 \%$ in 2003 to $92.5 \%$ and above 2015 , which together with the increase milking often leads to a decrease in fat and protein content in milk and reproductive capacity [17]. Of the other (in addition to conditional blood) genetic factors note a marked effect on the phenotypic variability of economically beneficial traits of parental origin (inheritance) and linear affiliation [3, 4, 8, 18, 19].

Formation and manifestation of traits (genotype implementation) occurs under the essential influence of specific environmental conditions. Therefore, the phenotype of the animal is only the norm of the genotype response to specific paratypic growing and retention conditions [13]. In view of the above, it is proposed to carry out periodic breeding and genetic monitoring in factory flocks and breeds $[2,8,11,12,15,20,21]$. The system of complex analysis consists in the assessment of individual development and manifestation of economically useful features of cows and heifers of different breeds, intraspecific types, conditional blood counts for improving breeds, lines, families, groups 
of half-sisters by paternal, total intra, intergroup and relative variability, variability genetic and environmental factors, the degree of phenotypic consolidation of breeding groups of different levels of intrathoracic hierarchy and their compatibility [12]. In modern world breeding practice, the dynamics of population-genetic parameters in the interaction "genotype - environment" is determined depend-ing on the breed [22, 23, 31, 34], country or geographical region of breeding $[16,25,30-32]$, tem-perature load [24, 26], organic animal husbandry [28, 29], voluntary milking technology [33], produc-tivity level [27] and other factors.

In the process of improving dairy breeds, considerable attention is paid to improving the ability to feed, the ability to maintain and milk, the quality of milk, the life expectancy of animals, economic maturity, and so on. However, dairy productivity remains the main breeding ground for dairy cattle. It is known about the significant influence of paratypic factors on qualitative and quantitative signs of milk productivity [3, 8, 19-21]. Under such conditions, genetic improvement of the dairy cattle array can be expected with the successful selection of the fruit enhancers desired.

The purpose of this study was to evaluate the influence of genotypic factors on the economic usefulness of dairy cattle.

Materials and methods. The study was conducted on the basis of primary breeding records in the herd of Ukrainian Red-and-White dairy breed of the State Enterprise experienced farm "Hristinovske" of the Institute of animal breeding and genetics nd. a. M.V.Zubets of National Academy of Agrarian Science. Based on the materials of the SUMS ORSEC electronic information database on 2017, using the interface developed by us (O. O. Bokov, Yu. P. Polupan), an observation matrix was formed in "*.sta" format, which contained data on 448 variables of 1540 cows, 912 of which had dated milk production information for the first lactation with calving during 1999-2017.

Given the methodological incorrectness of comparing the productivity of cows of different breeding groups under conditions of probably different levels of their cultivation and feeding in chronologically distant years $[3,8]$, the average yield of first-calf cows herds by years of first calving was calculated to substantiate the accounting period (table 1).

1. Dynamics of dairy productivity of the first-calf cow by years of the first calving

\begin{tabular}{|c|c|c|c|c|c|}
\hline \multirow{2}{*}{$\begin{array}{c}\text { Group by year } \\
\text { calving }\end{array}$} & \multirow{2}{*}{$\begin{array}{c}\text { Considered } \\
\text { animals }\end{array}$} & \multicolumn{2}{|c|}{ Milk yield for 305 days } & \multicolumn{2}{|c|}{ Fat content in milk, $\%$} \\
\cline { 3 - 6 } & 4 & $x \pm S . E$. & $\sigma$ & $x \pm S . E$. & $\sigma$ \\
\hline 1999 & 2 & $2571 \pm 301.6$ & 603.2 & $3.38 \pm 0.083$ & 0.167 \\
\hline 2000 & 7 & $2918 \pm 255.0$ & 360.6 & $3.34 \pm 0.188$ & 0.265 \\
\hline 2001 & 10 & $4290 \pm 410.9$ & 1087.4 & $3.41 \pm 0.010$ & 0.026 \\
\hline 2002 & 4 & $5211 \pm 291.2$ & 920.8 & $3.78 \pm 0.029$ & 0.090 \\
\hline 2003 & 26 & $5227 \pm 259.2$ & 518.4 & $3.79 \pm 0.022$ & 0.043 \\
\hline 2004 & 10 & $4715 \pm 176.7$ & 900.7 & $3.86 \pm 0.014$ & 0.074 \\
\hline 2005 & 23 & $4880 \pm 212.4$ & 1018.7 & $3.66 \pm 0.015$ & 0.072 \\
\hline 2006 & 26 & $4450 \pm 209.9$ & 1070.4 & $3.81 \pm 0.057$ & 0.286 \\
\hline 2007 & 118 & $4826 \pm 73.9$ & 802.5 & $3.77 \pm 0.009$ & 0.095 \\
\hline 2008 & 85 & $5199 \pm 121.3$ & 1118.7 & $3.89 \pm 0.120$ & 0.267 \\
\hline 2009 & 62 & $7009 \pm 151.4$ & 1192.6 & $3.96 \pm 0.057$ & 0.289 \\
\hline 2010 & 61 & $5865 \pm 154.1$ & 1203.3 & $3.95 \pm 0.060$ & 0.403 \\
\hline 2011 & 92 & $6552 \pm 102.6$ & 984.4 & $3.81 \pm 0.019$ & 0.128 \\
\hline 2012 & 95 & $5938 \pm 116.3$ & 1133.2 & $4.02 \pm 0.112$ & 0.623 \\
\hline 2013 & 98 & $5959 \pm 102.1$ & 1010.6 & $3.86 \pm 0.061$ & 0.563 \\
\hline 2014 & 98 & $7106 \pm 112.9$ & 1117.7 & $3.79 \pm 0.078$ & 0.708 \\
\hline 2015 & 90 & $6466 \pm 108.7$ & 1031.6 & $3.87 \pm 0.055$ & 0.502 \\
\hline 2016 & 911 & $5994 \pm 44.4$ & 1339.5 & $3.83 \pm 0.017$ & 0.435 \\
\hline At the average & & & & & 0.052 \\
\hline
\end{tabular}

The average milk yield for 305 days of lactation of the first-calf cow herds in the last 18 years has ranged from $2571 \mathrm{~kg}$ in 1999 calving to $7106 \mathrm{~kg}$ in 2015 . The fat content of milk ranged from $3.34 \%$ (2000) to $4.02 \%$ (2013). In general, the curvilinear increase in milk yields of the first-calf cow in the analyzed years reaches more than $4500 \mathrm{~kg}$ or almost 2.8 times. In such circumstances, it is 
considered methodically incorrect to determine the force of influence of factors and to compare group averages, given the likely different level of rearing and feeding of animals of different genetic groups in chronologically different years.

Due to the revealed chronological dynamics of the average productivity of first-calf cows in the formed database, a sufficiently homogeneous cluster of first-calf cows of 2010-2016 calves was isolated with a total livestock of 596 cows. During this period, the yield level for the years ranged from $5865-7106 \mathrm{~kg}$ with a limit of $1241 \mathrm{~kg}$. The weighted arithmetic mean of the yield of first-calf cows in these years was $6412 \mathrm{~kg}$. To determine the level of deviation of individual variants from the average level over this period, the normalized deviation was calculated. It ranged from 0.62 in animals in 2015 to -0.45 in 2011 in calving years. Comparisons of different breeding groups of animals on economically useful traits during the specified period were considered methodically correct.

The experimental animals that were calved during the control period are the daughters of 31 boogies, belonging mainly to 12 lines and related groups and related to two (Ukrainian Red-andWhite dairy and Holstein) breeds.

The calculations were performed by the methods of mathematical statistics by means of the software package "STATISTICA-12.0" on the PC [1]. The degree of consolidation of different groups of animals by 305 days of first lactation was determined by our proposed coefficients [10] using the standard deviation (K1) and the coefficient of variability (K2). The influence of the studied genetic and paratypic factors was calculated by one-way ANOVA as a ratio of factorial and total variance [9].

Research results. An analysis of age-related dynamics of dairy productivity revealed the regular growth of milk yields in the herd from the first to the third lactation (table 2). The milk yield of full-grown cows has increased by almost $400 \mathrm{~kg}$ compared to first-calf cows. During the studied period, milk yield and fat content for the first lactation of a cow of the herd exceed the standards of the Ukrainian Red-and-White dairy breed established by the instruction for boning.

2. Productivity for 305 days of lactation of cows of different breeds and conditional blood

\begin{tabular}{|c|c|c|c|c|c|c|c|c|}
\hline \multirow{4}{*}{\multicolumn{2}{|c|}{ Index }} & \multicolumn{6}{|c|}{ A group of cows by breed and conditional blood } & \multirow{4}{*}{$\begin{array}{l}\text { Total of } \\
\text { the herd }\end{array}$} \\
\hline & & \multirow{3}{*}{ together } & \multicolumn{4}{|c|}{ Ukrainian Red-and-White dairy } & \multirow{3}{*}{ Holstein } & \\
\hline & & & \multicolumn{4}{|c|}{ including Holstein blood, $\%$} & & \\
\hline & & & to 75 & $75-87.5$ & $87.5-93.7$ & $93.8-96$ & & \\
\hline \multicolumn{9}{|c|}{ The first lactation } \\
\hline \multicolumn{2}{|c|}{ Counted cows } & 519 & 10 & 325 & 50 & 117 & 77 & 596 \\
\hline \multicolumn{2}{|c|}{ Milk yield, kg } & $6360 \pm 50.5$ & $6305 \pm 292.3$ & $6257 \pm 61.3$ & $6498 \pm 152.9$ & $6632 \pm 110.7$ & $6764 \pm 149.7$ & $6412 \pm 48.3$ \\
\hline \multirow{2}{*}{$\begin{array}{l}\text { Content in } \\
\text { milk, \% }\end{array}$} & fat & $3.87 \pm 0.027$ & $4.20 \pm 0.246$ & $3.86 \pm 0.034$ & $3.91 \pm 0.071$ & $3.81 \pm 0.059$ & $3.89 \pm 0.078$ & $3.87 \pm 0.026$ \\
\hline & protein & $2.98 \pm 0.021$ & $3.16 \pm 0.150$ & $2.96 \pm 0.026$ & $2.97 \pm 0.070$ & $3.05 \pm 0.042$ & $3.04 \pm 0.046$ & $2.99 \pm 0.019$ \\
\hline \multicolumn{9}{|c|}{ The second lactation } \\
\hline \multicolumn{2}{|c|}{ Counted cows } & 298 & 4 & 202 & 32 & 56 & 35 & 333 \\
\hline \multicolumn{2}{|c|}{ Milk yield, kg } & $6640 \pm 69.1$ & $7035 \pm 353.2$ & $6607 \pm 84.2$ & $6801 \pm 180.4$ & $6652 \pm 179.1$ & $6930 \pm 246.4$ & $6670 \pm 67.1$ \\
\hline \multirow{2}{*}{$\begin{array}{l}\text { Content in } \\
\text { milk, \% }\end{array}$} & fat & $3.79 \pm 0.033$ & $3.96 \pm 0.066$ & $3.77 \pm 0.042$ & $3.83 \pm 0.084$ & $3.87 \pm 0.069$ & $3.81 \pm 0.118$ & $3.79 \pm 0.032$ \\
\hline & protein & $2.96 \pm 0.024$ & $3.06 \pm 0.058$ & $2.97 \pm 0.030$ & $3.04 \pm 0.100$ & $2.90 \pm 0.042$ & $2.91 \pm 0.068$ & $2.95 \pm 0.023$ \\
\hline \multicolumn{9}{|c|}{ Third lactation } \\
\hline \multicolumn{2}{|c|}{ Counted cows } & 176 & \begin{tabular}{|l|}
3 \\
\end{tabular} & 112 & \begin{tabular}{|l|l|}
24 \\
\end{tabular} & \begin{tabular}{|l|}
37 \\
\end{tabular} & \begin{tabular}{|l|l|}
15 & \\
\end{tabular} & 191 \\
\hline \multicolumn{2}{|c|}{ Milk yield, $\mathrm{kg}$} & $6824 \pm 101.7$ & $7167 \pm 143.2$ & $6851 \pm 131.8$ & $6582 \pm 253.3$ & $6872 \pm 209.9$ & $6644 \pm 306.5$ & $6810 \pm 95.7$ \\
\hline \multirow{2}{*}{$\begin{array}{l}\text { Content in } \\
\text { milk, } \%\end{array}$} & fat & $3.73 \pm 0.045$ & $3.91 \pm 0.149$ & $3.67 \pm 0.057$ & $3.86 \pm 0.131$ & $3.80 \pm 0.094$ & $3.75 \pm 0.288$ & $3.73 \pm 0.045$ \\
\hline & protein & $2.96 \pm 0.029$ & $3.00 \pm 0.222$ & $2.93 \pm 0.038$ & $2.97 \pm 0.070$ & $3.04 \pm 0.067$ & $2.92 \pm 0.060$ & $2.96 \pm 0.028$ \\
\hline
\end{tabular}

In State enterprise experienced farm "Hristinovske" the individual attachment of the captives by the mother stock is carried out taking into account the share of heredity by the Holstein breed. For the first-calf cow, there was a tendency for a curvilinear increase in productivity with an increase in the conditional share of heredity in the Holstein breed (table 2). Between the high-blooded milk yields (93.8-96\%, approaching relatively purebreds in the breed of improvement) and cows with a relative hardness of $75-87.5 \%$, the advantage of the former reaches $375 \pm 126.5 \mathrm{~kg}\left(\mathrm{t}_{\mathrm{d}}=2.96, \mathrm{P}<0.01\right)$. For the second and third lactation, the intergroup difference in yield is almost offset. 
In the cross-sectional comparison, a statistically significant excess of milk yield of Holstein first-calf cows over such cows of Ukrainian Red-and-White dairy breed was found $(404 \pm 158.0 \mathrm{~kg}$, $\left.\mathrm{t}_{\mathrm{d}}=2.57, \mathrm{P}<0.02\right)$. In the second lactation, this difference is reduced to an unreliable level, and in the third lactation Holstein cows are even slightly inferior to the peers of the Ukrainian Red-andWhite dairy breed. The predominance of Holstein cows on milk yield during the first lactation may be due to higher growth rate and earlier sexual and economic maturation of heifers. First-timers demonstrate the realization of the genetic potential of the breed, however, with age, the influence of environmental factors leads to the elimination of intergenerational differences in productivity. In oldage cows, this advantage is offset. Concerning the qualitative indicators of milk, probable unidirectional patterns of intergroup differentiation of cows of different breeds and conditional blood were not revealed.

Other genetic factors have investigated the differentiation of cow groups of different linear lineages and parental origin (half-sisters). For the analysis of intergroup differentiation by the milking of first-calf cows, the cows of the eight most numerous herds in the herd and related groups with dated productivity of more than 10 animals were selected. It was found (table 3 ) that cows of the Astronaut 1458744 line had the highest milk yields (7\% higher than the average of the herd) for the first lactation. The average expectation for the flock was 3-4\% higher than the first-calf cows of the Cavalier 1620273 and Hanover 1629391 lines. Lower than average dairy productivity is characterized by the first-calf cow of the lineages and related groups of Enhancer 343514, Improver 333471 and Chief 1427381. In many cases, the intergroup difference reaches a statistically significant level (up to $\mathrm{P}<0.01$ ).

3. Average milk yield of the first-calf cows of different lines

\begin{tabular}{|l|c|c|c|}
\hline \multicolumn{1}{|c|}{ Line, a related group } & Considered animals & $x \pm S . E ., \kappa g$ & C.V., $\%$ \\
\hline R. Citation 267150 & 119 & $6514.7 \pm 112.47$ & 18.83 \\
\hline Chief 1427381 & 123 & $6338.6 \pm 100.14$ & 17.52 \\
\hline Hanover 1629391 & 102 & $6611.0 \pm 103.74$ & 15.85 \\
\hline Improver 333471 & 79 & $6269.8 \pm 141.12$ & 20.00 \\
\hline Enhancer 343514 & 62 & $6225.5 \pm 147.12$ & 18.61 \\
\hline Cavalier 1620273 & 28 & $6708.2 \pm 193.11$ & 15.23 \\
\hline Starbuck 352790 & 28 & $6482.2 \pm 225.89$ & 18.44 \\
\hline Astronaut 1458744 & 11 & $6884.4 \pm 471.44$ & 15.86 \\
\hline At average over the accounting period & 585 & $6408.2 \pm 48.55$ & 18.40 \\
\hline
\end{tabular}

Even more significant was the differentiation on milk yield for the 305 days of the first lactation of groups of half-sisters by father (table 4). The predominance of the best in this indicator of the daughters of the sire Soloist 7959 of the Ukrainian Red-and-White dairy breed over the peers of the sire Inhibitor 402151 of the Holstein breed reaches $1050 \pm 491.6 \mathrm{~kg}$ or $17.4 \%(\mathrm{P}<0.05)$. The performance of the daughters of the bulls Mitchell Red 402213 and Tumpi Et Red Tl 112367468 was also significantly higher than the mean. The deteriorating yields of the first-calf cows in the studied herd were Holstein bulls Inhibitor Et Red 402151, Jopi Red Tv T1 114386090, and sire Ukrainian Redand-White dairy breed May 5573.

4. Characteristic of the half-sisters groups of the father by milk yields of first-calf cows

\begin{tabular}{|l|c|c|c|c|c|c|}
\hline \multicolumn{1}{|c|}{ Father } & Considered animals & $x \pm$ S.E., $\mathrm{kg}$ & S.D., $\mathrm{kg}$ & C.V., $\%$ & $K_{1}$ & $K_{2}$ \\
\hline Soloist 7959 & 10 & $7096 \pm 465.8$ & 1472.9 & 20.8 & -0.254 & -0.133 \\
\hline Mitchell Red 402213 & 13 & $7033 \pm 323.8$ & 1167.6 & 16.6 & 0.006 & 0.094 \\
\hline Tumpi Et Red T1 112367468 & 13 & $7006 \pm 305.9$ & 1103.0 & 15.7 & 0.061 & 0.141 \\
\hline Benaro Et Red T1 359855968 & 94 & $6657 \pm 107.5$ & 1042.5 & 15.7 & 0.112 & 0.146 \\
\hline Konbeo Red Tv T1 579810507 & 26 & $6612 \pm 195.1$ & 995.0 & 15.1 & 0.153 & 0.179 \\
\hline Diplomat Et Red 401497 & 118 & $6528 \pm 112.6$ & 1222.9 & 18.7 & -0.041 & -0.022 \\
\hline Roman Red Tv Tl 660886883 & 19 & $6465 \pm 317.5$ & 1383.9 & 21.4 & -0.178 & -0.168 \\
\hline May 5573 & 76 & $6226 \pm 140.6$ & 1225.9 & 19.7 & -0.044 & -0.074 \\
\hline Jopi Red Tv Tl 114386090 & 91 & $6240 \pm 112.7$ & 1075.3 & 17.2 & 0.084 & 0.060 \\
\hline Inhibitor Et Red 402151 & 47 & $6046 \pm 157.1$ & 1077.2 & 17.8 & 0.083 & 0.028 \\
\hline
\end{tabular}


Estimates of the degree of phenotypic consolidation by both methods impersonal were bulls Solist 7959, Roman Et Red TV TL 660886883, May 5573 and Diplomat Et Red 401497.

A noticeable narrowing of the phenotypic variability in daughters' daughters was found in the relatively pre-present congeners of Konbeo Red Tv T1 579810507, Benaro Et Red Tv 359855968, Tumpi Et Red Tl 112367468, Jopi Red Tv Tl 11438602, Inhibitor Et Red 402151 and Mitchell Red 402213.

Therefore, in combination with estimates of enhancing effect and phenotypic consolidation, prepotent enhancers of Tumpi Et Red T1 112367468 and Mitchell Red 402213, and the most undesirable ones are prepotent aggravating Inhibitor Et Red 402151 and Jopi Red Tv Tl 114386090.

An analysis of variance confirmed the presence of the influence of the genetic factors studied on the overall phenotypic variability of not only dairy productivity but also other economically beneficial traits of cows of the herd of the State Enterprise experienced farm "Hristinovske" (table 5).

5. The influence of genetic factors on the phenotypic variability of economically beneficial traits of cows

\begin{tabular}{|c|c|c|c|c|c|c|c|}
\hline \multirow{3}{*}{\multicolumn{4}{|c|}{ Sign }} & \multicolumn{4}{|c|}{ The influence of the organized factor: } \\
\hline & & & & \multicolumn{2}{|c|}{ line, a related group } & \multicolumn{2}{|c|}{ father } \\
\hline & & & & $\eta^{2}{ }_{x} \pm S . E ., \%$ & $P$ & $\eta_{x}^{2} \pm S . E ., \%$ & $P$ \\
\hline \multirow{2}{*}{\multicolumn{2}{|c|}{$\begin{array}{l}\text { Number of degrees of } \\
\text { freedom: }\end{array}$}} & \multicolumn{2}{|c|}{ factorial } & \multicolumn{2}{|l|}{13} & \multicolumn{2}{|l|}{31} \\
\hline & & \multicolumn{2}{|c|}{ general } & \multicolumn{2}{|c|}{571} & \multicolumn{2}{|c|}{553} \\
\hline \multirow{6}{*}{$\begin{array}{l}\text { Live weight in } \\
\text { age: }\end{array}$} & \multirow{3}{*}{ months: } & \multicolumn{2}{|c|}{6} & $9.5 \pm 5.14$ & 0.027 & $11.4 \pm 8.15$ & 0.080 \\
\hline & & \multicolumn{2}{|l|}{12} & $11.1 \pm 5.03$ & 0.007 & $11.7 \pm 7.48$ & 0.041 \\
\hline & & \multicolumn{2}{|l|}{18} & $10.7 \pm 4.53$ & 0.005 & $16.8 \pm 6.84$ & $<0.001$ \\
\hline & \multirow{3}{*}{ calving: } & \multicolumn{2}{|l|}{1} & $9.8 \pm 3.24$ & $<0.001$ & $21.6 \pm 6.79$ & $<0.001$ \\
\hline & & \multicolumn{2}{|l|}{2} & $14.4 \pm 4.47$ & $<0.001$ & $16.5 \pm 7.31$ & $<0.001$ \\
\hline & & \multicolumn{2}{|l|}{3} & $9.3 \pm 8.02$ & 0.245 & $17.8 \pm 13.51$ & 0.084 \\
\hline \multirow{9}{*}{$\begin{array}{l}\text { For } 305 \text { days } \\
\text { lactation: }\end{array}$} & \multirow{3}{*}{ first } & \multicolumn{2}{|c|}{ milk yield } & $4.0 \pm 2.27$ & 0.034 & $9.2 \pm 5.56$ & 0.005 \\
\hline & & \multirow{2}{*}{$\begin{array}{l}\text { content in } \\
\text { milk: }\end{array}$} & fat & $3.1 \pm 3.34$ & 0.493 & $7.2 \pm 7.73$ & 0.466 \\
\hline & & & protein & $7.6 \pm 3.71$ & 0.014 & $11.0 \pm 7.65$ & 0.048 \\
\hline & \multirow{3}{*}{ second: } & \multicolumn{2}{|c|}{\begin{tabular}{|l|} 
milk yield \\
\end{tabular}} & $2.8 \pm 3.78$ & 0.696 & $7.3 \pm 8.18$ & 0.530 \\
\hline & & \multirow{2}{*}{$\begin{array}{l}\text { content in } \\
\text { milk: }\end{array}$} & fat & $3.1 \pm 4.42$ & 0.707 & $8.7 \pm 10.20$ & 0.556 \\
\hline & & & protein & $14.0 \pm 4.65$ & $<0.001$ & $17.0 \pm 10.73$ & 0.014 \\
\hline & \multirow{3}{*}{ third: } & \multicolumn{2}{|c|}{ milk yield } & $8.1 \pm 6.74$ & 0.223 & $17.6 \pm 12.76$ & 0.046 \\
\hline & & \multirow{2}{*}{$\begin{array}{l}\text { content in } \\
\text { milk: }\end{array}$} & fat & $7.5 \pm 8.48$ & 0.500 & $18.4 \pm 16.10$ & 0.162 \\
\hline & & & protein & $7.8 \pm 8.41$ & 0.448 & $14.0 \pm 16.20$ & 0.484 \\
\hline \multicolumn{4}{|c|}{ Age of first calving } & $11.7 \pm 1.86$ & $<0.001$ & $17.2 \pm 4.78$ & $<0.001$ \\
\hline \multirow{3}{*}{\multicolumn{2}{|c|}{$\begin{array}{l}\text { The length of time between } \\
\text { the calving: }\end{array}$}} & \multicolumn{2}{|c|}{$1 \mathrm{i} 2$} & $5.8 \pm 2.68$ & 0.008 & $12.5 \pm 6.39$ & $<0.001$ \\
\hline & & \multicolumn{2}{|c|}{2 i3 } & $7.1 \pm 4.63$ & 0.082 & $11.7 \pm 10.06$ & 0.163 \\
\hline & & $3 \mathrm{i} 4$ & & $11.2 \pm 8.17$ & 0.128 & $15.6 \pm 15.73$ & 0.310 \\
\hline
\end{tabular}

Belonging to a lineage or related group has a relatively low but significant effect on the phenotypic variability of milk yield and protein content of first-calf cow milk. By protein content, the influence of the specified genetic factor prolongs (even doubles) to the second lactation. The effect of linear affiliation on the live weight of heifers and cows after the first two calves, the age of the first calving and the length of time between the first two calves were statistically significant.

The influence of parental origin (inheritance) in most cases exceeds that of linear affiliation. From the signs of dairy productivity, the influence of the father on the variability of milk yield for the first and third milk and the protein content in milk for the first and second lactation was significant. At the third level of statistical significance, a significant effect of paternal origin was found on the phenotypic variability of age of first calving, duration of period between first and second calving, live weight of calves at one and a half years, and cows after the first two calves. There was no statistically significant influence of the father (as well as linear affiliation) on the fat content of cows' milk.

At average, the influence of parental origin on the traits studied is $13.1 \%$ versus $8.3 \%$ for lineage or related group affiliation. That is, the influence of the father in the studied herd is 1.58 times more significant than such linear affiliation. This corresponds to the regularities revealed in our previous studies in other herds and confirms the theoretical expectation of the highest influence at the 
basic level of the intrabreed system hierarchical structure $[3,4,11,12]$. Therefore, when selecting the fetuses, their linear identity should be taken into account with the unconditional priority of the breeding value of the bulls for posterity.

Conclusions. In the process of breeding work, there is a positive trend in the productivity growth of dairy cattle in the State Enterprise experienced farm "Hristinovske". The biological regularity of cows to increase dairy productivity with age is realized.

For the first-calf cows, there was a tendency for curvilinear productivity increase with an increase in the conditional share of heredity in the Holstein breed. In the interspecific comparison, a statistically significant excess of the Holstein milk yields over such cows of the Ukrainian Red-andWhite dairy breed $\left(404 \pm 158.0 \mathrm{~kg}, \mathrm{t}_{\mathrm{d}}=2.57, \mathrm{P}<0.02\right)$ was established, which is leveled by the third lactation.

A statistically significant influence of linear affiliation (on average $8.3 \%$ ) and parental origin $(13.1 \%)$ on the variability of individual signs of live weight, milk production and reproductive capacity of cows was established. The influence of the parent in the study herd is 1.58 times more significant than such linear membership.

A significant level of differentiation of groups of cows of different lines, related groups and half-sisters by father for milk yield for the first lactation was revealed. Combining estimates of the enhancing effect and phenotypic consolidation, the most desirable for further use in the herd are the prepotent enhancers Tumpi Et Red T1 112367468 and Mitchell Red 402213, and the most undesirable are the pretentious aggravating Inhibitors ET Red 403860 and Jopi Red Tv Tl 114386090.

\section{BIBLIOGRAPHY}

1. Боровиков, В. П. STATISTICA. Искусство анализа данных на компьютере: для профессионалов / В. П. Боровиков. - СПб : Питер, 2003. - 688 с.

2. Буркат, В. П. Виведення червоно-рябої молочної породи / В. П. Буркат, О. Ф. Хаврук // Тваринництво України. - 1991. - № 6. - С. 12-14.

3. Вплив генетичних і паратипових чинників на господарськи корисні ознаки корів / М. В. Гладій, Ю. П. Полупан, І. В. Базишина, І. М. Безрутченко, Н. Л. Полупан // Розведення і генетика тварин. - Київ, 2014. - Вип. 48. - С. 48-61.

4. Вплив походження за батьком і лінійної належності на господарськи корисні ознаки корів / М. В. Гладій, Ю.П.Полупан, .В.Базишина, Н.Л.Полупан, .М.Безрутченко // Вісник Сумського національного аграрного університету. Серія “Тваринництво”. - 2014. Вип. 7 (26). - С. 3-11.

5. Генетичні ресурси молочного і м'ясного скотарства в Україні / М. Гладій, Ю. Полупан, Н. Рєзникова, С. Прийма // Тваринництво України. - 2018. - № 9-10. - С. 13-20.

6. Державний реєстр суб'єктів племінної справи у тваринництві за 2018 рік / О. В. Романова, С. В. Прийма, Ю. П. Полупан, Д. М. Басовський ; заг. ред. С. В. Прийми. - Київ, 2019. Том II. - 204 с. - Режим доступу: http://www.animalbreedingcenter.org.ua/derjplemreestr

7. Зубець, М. В. Породна структура і перспективи селекції молочної худоби / М. В. Зубець, М. І. Бащенко, Ю. П. Полупан // Вісник аграрної науки. - 2012. - № 10. - С. 34-38.

8. Іляшенко, Г. Д. Вплив генетичних та паратипних чинників на молочну продуктивність корів української червоної та чорно-рябої молочних порід / Г. Д. Іляшенко, Ю. П. Полупан // Вісник степу. - Кіровоград, 2009. - Вип. 6. - С. 129-136.

9. Плохинский, Н. А. Биометрия / Н. А. Плохинский. - Москва : Изд-во МГУ, 1970. - 367 с.

10. Полупан, Ю. П. Методи визначення ступеня фенотипової консолідації селекційних груп тварин / Ю. П. Полупан // Вісник аграрної науки. - 2002. - № 1. - С. 48-52.

11. Полупан, Ю. П. Мониторинг селекционно-генетической ситуации в стадах молочного скота / Ю. П. Полупан, Н. С. Гавриленко, А. А. Пожилов // Повышение интенсивности и конкурентоспособности отраслей животноводства : тез. докл. Междунар. науч.-практ. конф. (1415 сент. 2011 г.). - Жодино : РУП “Научно-практический центр Национальной академии наук Беларуси по животноводству”, 2011. - Ч. 1. - С. 147-149. 
12. Полупан, Ю. П. Селекційно-генетичний моніторинг у заводських стадах молочної худоби / Ю. П. Полупан, М. С. Гавриленко // Вісник аграрної науки. - 2008. - № 8. - С. 38.

13. Полупан, Ю. П. Суб'єктивні акценти з деяких питань генетичних основ селекції та породоутворення / Ю. П. Полупан // Розведення і генетика тварин. - Київ : Аграр. наука, 2007. Вип. 41. - С. 194-208.

14. Програма удосконалення та організації ведення селекційного процесу в українській червоно-рябій молочній породі великої рогатої худоби на перспективу до 2020 року / А. А. Гетя, Н. В. Кудрявська, О. І. Костенко, М. І. Бащенко, С. Ю. Рубан, О. Д. Бірюкова, Г. С. Коваленко, В. П. Шабля, В. О. Даншин, П. І. Шаран, С. В. Кузебний, Д. М. Басовський, Н. В. Швець, Т. О. Кругляк, Г. О. Гольоса, А. П. Кругляк, С. І. Терехов. - Чубинське, 2013. - 59 с.

15. Рубан, С. Ю. Обгрунтування параметрів екстер'єрної оцінки молочної худоби / С. Ю. Рубан // Вісник аграрної науки . - 2003. - № 8. - С. 71-73.

16. Светова, Ю. А. Рост и развитие телок голштинской породы различного екогенеза/ Ю. А. Светова, Т. А. Гусева // Зоотехния. - 2014. - № 10. - С. 17-18.

17. Українська червоно-ряба молочна порода / М. І. Бащенко, Ю. Ф. Мельник, А. П. Кругляк, О. Д. Бірюкова, Ю. П. Полупан, Т. О. Кругляк // Селекційні, генетичні та біотехнологічні методи удосконалення і збереження генофонду порід сільськогосподарських тварин ; за ред. М. В. Гладія і Ю. П. Полупана. - Полтава : ТОВ «Фірма «Техсервіс», 2018. - С. 209-253.

18. Федорович, С. І. Молочна продуктивність високопродуктивних корів та їх потомків прикарпатського внутрішньопородного типу української червоно-рябої молочної породи / Є. І. Федорович, О. Ю. Ільницька, Н. П. Бабік // Розведення і генетика тварин. - Київ, 2016. Вип. 52. - С. 119-128.

19. Фураева, Н. Влияние наследственных и ненаследственных факторов на фенотипическую изменчивость молочной продуктивности первотелок ярославской породы / Н. Фураева, Л. Москаленко, Н. Муравьева // Молочное и мясное скотоводство. - 2012. - № 6. - С. 9-10.

20. Хмельничий, Л. М. Вплив популяційно-генетичних та паратипових чинників на ознаки молочної продуктивності корів української червоно-рябої молочної породи / Л. М. Хмельничий, В. П. Лобода // Вісник Сумського національного аграрного університету. Серія "Тваринництво". - 2015. - Вип. 2 (27). - С. 27-31.

21. Хмельничий, Л. М. Генотипові та паратипові чинники впливу на ознаки молочної продуктивності корів української чорно-рябої молочної породи / Л. М. Хмельничий, В. В. Вечорка // Вісник Сумського національного аграрного університету. Серія “Тваринництво”. - 2014. - Вип. 7 (26). - С. 87-90.

22. Estimates of genetic parameters and eigenvector indices for milk production of Holstein cows / R. P. Savegnago, G. J. M. Rosa, B. D. Valente, L. G. G. Herrera, R. L. R. Carneiro, R. C. Sesana, L. El Faro, D. P. Munari // J. Dairy Sci. - 2013. - Vol. 96, is. 11. - P. 7284-7293.

23. Estimation of genetic parameters for novel functional traits in Brown Swiss cattle / M. Kramer, M. Erbe, B. Bapst, A. Bieber, H. Simianer // J. Dairy Sci. - 2013. - Vol. 96, Is. 9. - P. 5954-5964.

24. Estimation of the genetic milk yield parameters of Holstein cattle under heat stress in South Korea / SeokHyun Lee, ChangHee Do, YunHo Choy, ChangGwon Dang, Alam Mahboob, and Kwanghyun Cho // Asian-Australasian J. Anim. Sci. - 2019. - Vol. 32, no. 3. - P. 334-340.

25. Genetic variance in micro-environmental sensitivity for milk and milk quality in Walloon Holstein cattle / J. Vandenplas, C. Bastin, N. Gengler, H. A. Mulder // J. Dairy Sci. - 2013. - Vol. 96, is. 9. - P. 5977-5990.

26. Genetic parameters for milk fatty acids, milk yield and quality traits of a Holstein cattle population reared under tropical conditions / J. Petrini, L. H. S. Iung, M. A. P. Rodriguez, M. Salvian, F. Pértille, G. A. Rovadoscki, L. D. Cassoli, L. L. Coutinho, P. F. Machado, G. R. Wiggans, and G. B. Mourão // J. Anim. Breed. Genet. - 2016. - Vol. 133. - P. 384-395.

27. Genotype by environment interaction for activity-based estrus traits in relation to production level for Danish Holstein / A. Ismael, E. Strandberg, B. Berglund, M. Kargo, A. Fogh, P. Løvendahl // J. Dairy Sci. - 2016. - Vol. 99. - P. 9834-9844. 
28. Genotype by environment interaction for female fertility traits under conventional and organic production systems in Danish Holsteins / A. Liu, G. Su, J. Höglund, Z. Zhang, J. Thomasen, I. Christiansen, Y. Wang, M. Kargo / J. of Dairy Sci. - 2019. - Vol. 102, is. 9. - P. 8134-8147.

29. Genotype by environment interaction of Swedish dairy cows in organic and conventional production systems / T. Sundberg, L. Rydhmer, W. F. Fikse, B. Berglund, E. Strandberg // Acta Agric. Scand. A Anim. Sci. - 2010. - Vol. 60, is. 2. - P. 65-73.

30. Genomic selection improves the possibility of applying multiple breeding programs in different environments / M. Slagboom, M. Kargo, A. C. Sørensen, J. R. Thomasen, H. A. Mulder // J. Dairy Sci. - 2019. - Vol. 102, is. 9. - P. 8197-8209.

31. Satoła, A. Genetic parameters of milk fat-to-protein ratio in first three lactations of Polish Holstein-Friesian cows / A. Satoła, E. Ptak // Journal of Animal and Feed Sciences. - 2019. - Vol. 28, no. 2. - P. 97-109.

32. Simultaneous estimation of genotype by environment interaction accounting for discrete and continuous environmental descriptors in Irish dairy cattle / J. J. Windig, H. A. Mulder, D. I. BohtheWilhelmus, R. F. Veerkamp // J. Dairy Sci. - 2011. - Vol. 94, is. 6. - P. 3137-3147.

33. Wethal, K. B. Genetic analyses of novel temperament and milkability traits in Norwegian Red cattle based on data from automatic milking systems / K. B. Wethal, B. Heringstad // J. Dairy Sci. 2019. - Vol. 102, is. 9. - P. 8221-8233.

34. Yao, C. Short communication: Genetic evaluation of stillbirth in US Brown Swiss and Jersey cattle / C. Yao, K. A. Weigel, J. B. Cole // J. Dairy Sci. - 2014. - Vol. 97, is. 4. - P. 2474-2480.

\section{REFERENCES}

1. Borovikov, V. P. 2003. STATISTICA. Iskusstvo analiza dannykh na komp'yutere: dlya professionalov - Art of analysis of data on a computer: for professionals. SPb : Piter, 688 (in Russian).

2. Burkat, V. P., and O. F. Khavruk. 1991. Vyvedennya chervono-ryaboyi molochnoyi porody Breeding of Red-and-White dairy breed. Tvarynnytstvo Ukrayiny - Animal husbandry of Ukraine. 6:12-14 (in Ukrainian).

3. Hladiy, M. V., Yu. P. Polupan, I. V. Bazyshyna, I. M. Bezrutchenko, and N. L. Polupan. 2014. Vplyv henetychnykh i paratypovykh chynnykiv na hospodars'ky korysni oznaky koriv - Influence of genetic and paratypic factors on economic useful signs of cows. Rozvedennya $i$ henetyka tvarynBreeding and genetics of animals. Kyyiv, 48:48-61 (in Ukrainian).

4. Hladiy, M. V., Yu. P. Polupan, I. V. Bazyshyna, N. L. Polupan, and I. M. Bezrutchenko. 2014. Vplyv pokhodzhennya za bat'kom i liniynoyi nalezhnosti na hospodars'ky korysni oznaky koriv Influence of origin after a father and linear belonging on economic useful signs of cows. Visnyk Sums'koho natsional'noho ahrarnoho universytetu. Seriya "Tvarynnytstvo". - Bulletin of the Sumy national agrarian university. Series "Animal husbandry". 7(26):3-11 (in Ukrainian).

5. Hladiy, M., Yu. Polupan, N. Ryeznykova, and S. Pryyma. 2018. Henetychni resursy molochnoho i m"yasnoho skotarstva $\mathrm{v}$ Ukrayini - Genetic resources of the dairy and meat cattle breeding are in Ukraine. Tvarynnytstvo Ukrayiny - Cattle breeding of Ukraine. 9-10:13-20 (in Ukrainian).

6. Romanova, O. V., S. V. Pryyma, Yu. P. Polupan, and D. M. Basovs'kyy. 2019. Derzhavnyy reyestr sub'yektiv pleminnoyi spravy u tvarynnytstvi za 2018 rik - State register subjectes of pedigree business in a animal husbandry for 2018. Kyyiv, 2:204. Rezhym dostupu: http://www.animalbreedingcenter.org.ua/derjplemreestr (in Ukrainian).

7. Zubets, M. V., M. I. Bashchenko, and Yu. P. Polupan. 2012. Porodna struktura i perspektyvy selektsiyi molochnoyi khudoby - Pedigree structure and prospects of selection of dairy cattle. Visnyk ahrarnoyi nauky - Herald of agrarian science. 10:34-38 (in Ukrainian).

8. Ilyashenko, H. D., and Yu. P. Polupan. 2009. Vplyv henetychnykh ta paratypnykh chynnykiv na molochnu produktyv-nist' koriv ukrayins'koyi chervonoyi ta chorno-ryaboyi molochnykh porid Influence of genetic and paratypic factors on the dairy productivity of cows of Ukrainian Red and Black-and-White dairy breeds. Visnyk stepu - Herald of steppe. Kirovohrad, 6:129-136 (in Ukrainian). 
9. Plokhynskyy, N. A. 1970. Byometryya-Biometry. Moskva : Yzd-vo MHU, 367 (in Russian).

10. Polupan, Yu. P. 2002. Metody vyznachennya stupenya fenotypovoyi konsolidatsiyi selektsiynykh hrup tvaryn - Methods of determination of degree of phenotypic consolidation of selection groups of animals. Visnyk ahrarnoyi nauky - Herald of Agrarian Science. 1:48-52 (in Ukrainian).

11. Polupan, Yu. P., N. S. Havrylenko, and A. A. Pozhylov. 2011. Monitoring selekcionno-geneticheskoj situacii v stadah moloch-nogo skota - Monitoring of selection-genetic situation in the herds of dairy cattle. Povyshenie intensivnosti i konkurentosposobnosti otraslej zhivotnovodstva - Increase of intensity and competitiveness of industries of Animal husbandry, tez. dokl. Mezhdunar. nauchno-prakt. konf. (14-15 sentjabrja 2011 g.). Zhodino: RUP "Nauchno-prakticheskij centr Nacional'noj akademii nauk Belarusi po zhivotnovodstvu”. 1:147-149 (in Russian).

12. Polupan, Yu. P., and M. S. Havrylenko. 2008. Selektsiyno-henetychnyy monitorynh u zavods'kykh stadakh molochnoyi khudoby - The selection-genetic monitoring is in the stud herds of dairy cattle. Visnyk ahrarnoyi nauky - Herald of Agrarian Science. 8:38 (in Ukrainian).

13. Polupan, Yu. P. 2007. Sub"yektyvni aktsenty z deyakykh pytan' henetychnykh osnov selektsiyi ta porodoutvorennya - Subjective accents on some questions of genetic bases of selection and breed generation. Rozvedennya i henetyka tvaryn - Breeding and genetics of animals. Kyyiv: Ahrarna nauka, 41:194-208 (in Ukrainian).

14. Hetya, A. A., N. V. Kudryavs'ka, O. I. Kostenko, M. I. Bashchenko, S. Yu. Ruban, O. D. Biryukova, H. S. Kovalenko, V. P. Shablya, V. O. Danshyn, P. I. Sharan, S. V. Kuzebnyy, D. M. Basovs'kyy, N. V. Shvets', T. O. Kruhlyak, H. O. Hol'osa, A. P. Kruhlyak, and S. I. Terekhov. 2013. Prohrama udoskonalennya ta orhanizatsiyi vedennya selektsiynoho protsesu $v$ ukrayins'kiy chervono-ryabiy molochniy porodi velykoyi rohatoyi khudoby na perspektyvu do 2020 roku - Program of improvement and organization of conduct of selection process in the Ukrainian Red-and-White dairy breed of cattle on a prospect to 2020 year. Chubyns'ke, 59 (in Ukrainian).

15. Ruban, S. Yu. 2003. Obgruntuvannya parametriv ekster"yernoyi otsinky molochnoyi khudoby - A ground of parameters of exterior estimation of dairy cattle. Visnyk ahrarnoyi nauky - Herald of Agrarian Science. 8:71-73 (in Ukrainian).

16. Svetova, Ju. A., and T. A. Guseva. 2014. Rost i razvitie telok golshtinskoj porody razlichnogo ekogeneza - Height and development of heifers of Holstein breed of different ecogenesis. Zootehnija - Zootechny. 10:17-18 (in Russian).

17. Bashchenko, M. I., Yu. F. Mel'nyk, A. P. Kruhlyak, O. D. Biryukova, Yu. P. Polupan, and T. O. Kruhlyak. 2018. Ukrayins'ka chervono-ryaba molochna poroda - Ukrainian Red-and-White dairy breed. Selektsiyni, henetychni ta biotekhnolohichni metody udoskonalennya i zberezhennya henofondu porid sil's'kohospodars'kykh tvaryn - Selection, genetic and biotechnological methods of improvement and maintenance of gene pool of breeds of agricultural animals. Poltava : TOV «Firma «Tekhservis», 209-253 (in Ukrainian).

18. Fedorovych, Ye. I., O. Yu. Il'nyts'ka, and N. P. Babik. 2016. Molochna produktyvnist' vysokoproduktyvnykh koriv ta yikh potomkiv prykarpat's'koho vnutrishn'oporodnoho typu ukrayins'koyi chervono-ryaboyi molochnoyi porody - The dairy productivity of high-performance cows and their descendants of the Prykarpattya interbreed type of the Ukrainian Red-and-White dairy breed. Rozvedennya $i$ henetyka tvaryn - Breeding and genetics of animals. Kyyiv, 52:119-128 (in Ukrainian).

19. Furaeva, N., L. Moskalenko, and N. Murav'eva. 2012. Vlijanie nasledstvennyh i nenasledstvennyh faktorov na fenotipi-cheskuju izmenchivost' molochnoj produktivnosti pervotelok jaroslavskoj porody - Influence of the inherited and uninherited factors on phenotypical changeability of the dairy productivity of first-calf calfs of the Yaroslavl breed. Molochnoe i mjasnoe skotovodstvo - Dairy and meat cattle breeding. 6:9-10 (in Russian).

20. Khmel'nychyy, L. M., and V. P. Loboda. 2015. Vplyv populyatsiyno-henetychnykh ta paratypovykh chynnykiv na oznaky molochnoyi produktyvnosti koriv ukrayins'koyi chervono-ryaboyi molochnoyi porody - Influence of population-genetic and paratype factors on the signs of the dairy 
productivity of cows of the Ukrainian Red-and-White dairy breed. Visnyk Sums'koho natsional'noho ahrarnoho universytetu. Seriya "Tvarynnytstvo"-Bulletin of the Sumy national agrarian university. Series "Animal husbandry". 2(27):27-31.

21. Khmel'nychyy, L. M., and V. V. Vechorka. 2014. Henotypovi ta paratypovi chynnyky vplyvu na oznaky molochnoyi produktyvnosti koriv ukrayins'koyi chorno-ryaboyi molochnoyi porody - To the genotype and paratype factors of influence on the signs of the dairy productivity of cows of the Ukrainian Black-and-White dairy breed. Visnyk Sums'koho natsional'noho ahrarnoho universytetu. Seriya "Tvarynnytstvo" - Bulletin of the Sumy national agrarian university. Series are "Animal husbandry", 7(26):87-90 (in Ukrainian).

22. Savegnago, R. P., G. J. M. Rosa, $\quad$ B. D. Valente, $\quad$ L. G. G. Herrera, R. L. R. Carneiro, R. C. Sesana, L. El Faro, and D. P. Munari. 2013. Estimates of genetic parameters and eigenvector indices for milk production of Holstein cows. J. Dairy Sci. 96:7284-7293.

23. Kramer, M., M. Erbe, B. Bapst, A. Bieber and H. Simianer. 2013. Estimation of genetic parameters for novel functional traits in Brown Swiss cattle. J. Dairy Sci. 96(9):5954-5964.

24. SeokHyun, Lee, ChangHee Do, YunHo Choy, ChangGwon Dang, Alam Mahboob, and Kwanghyun Cho. 2019. Estimation of the genetic milk yield parameters of Holstein cattle under heat stress in South Korea. Asian-Australasian J. Anim. Sci. 32(3):334-340.

25. Vandenplas, J., C. Bastin, N. Gengler, and H. A. Mulder. 2013. Genetic variance in microenvironmental sensitivity for milk and milk quality in Walloon Holstein cattle. J. Dairy Sci. 96(9):5977-5990.

26. Petrini, J., L. H. S. Iung, M. A. P. Rodriguez, M. Salvian, F. Pértille, G. A. Rovadoscki, L. D. Cassoli, L. L. Coutinho, P. F. Machado, G. R. Wiggans, and G. B. Mourão. 2016. Genetic parameters for milk fatty acids, milk yield and quality traits of a Holstein cattle population reared under tropical conditions. J. Anim. Breed. Genet. 133:384-395.

27. Ismael, A., E. Strandberg, B. Berglund, M. Kargo, A. Fogh, and P. Løvendahl. 2016. Genotype by environment interaction for activity-based estrus traits in relation to production level for Danish Holstein. J. Dairy Sci. 99:9834-9844.

28. Liu, A., G. Su, J. Höglund, Z. Zhang, J. Thomasen, I. Christiansen, Y. Wang, and M. Kargo. 2019. Genotype by environment interaction for female fertility traits under conventional and organic production systems in Danish Holsteins. J. Dairy Sci. 102(9):8134-8147.

29. Sundberg, T., L. Rydhmer, W. F. Fikse, B. Berglund and E. Strandberg. 2010. Genotype by environment interaction of Swedish dairy cows in organic and conventional production systems. Acta Agric. Scand. A Anim. Sci. 60(2):65-73.

30. Slagboom, M., M. Kargo, A. C. Sørensen, J. R. Thomasen, and H. A. Mulder. 2019. Genomic selection improves the possibility of applying multiple breeding programs in different environments. J. Dairy Sci. 102(9):8197-8209.

31. Satoła, A., and E. Ptak. 2019. Genetic parameters of milk fat-to-protein ratio in first three lactations of Polish Holstein-Friesian cows. Journal of Animal and Feed Sciences. 28(2):97-109.

32. Windig, J. J., H. A. Mulder, D. I. Bohthe-Wilhelmus, and R. F. Veerkamp. 2011. Simultaneous estimation of genotype by environment interaction accounting for discrete and continuous environmental descriptors in Irish dairy cattle. J. Dairy Sci. 94(6):3137-3147.

33. Wethal, K. B., and B. Heringstad. 2019. Genetic analyses of novel temperament and milkability traits in Norwegian Red cattle based on data from automatic milking systems. J. Dairy Sci. 102(9):8221-8233.

34. Yao, C., K. A. Weigel, and J. B. Cole. 2014. Short communication: Genetic evaluation of stillbirth in US Brown Swiss and Jersey cattle. J. Dairy Sci. 97(4):2474-2480. 